\title{
Extractives Industries and Conflict: Reduction of Risks Associated with Extractive Industries in Turkana County, Kenya
}

\author{
Fr. Areman L. Paul ${ }^{1}$, Prof. Joshua Kwonyike ${ }^{2}$, Prof. Leonard S. Mulongo ${ }^{3}$, Dr. David Kamar Imana ${ }^{4}$ \\ ${ }^{1} \mathrm{PhD}$ student at the School of Arts \& Social Sciences - Moi University, P.O. Box 3900, Eldoret - 30100, Kenya \\ ${ }^{2}$ Department of Management Science and Entrepreneurship \\ ${ }^{3}$ Department of Geography and Environmental Studies \\ ${ }^{4}$ Lecturer at Turkana University College, School of Business and Economics, P.O. Box 379 Lodwar - 30500, Kenya
}

\begin{abstract}
African countries endowed with natural resources, especially oil have seen violent conflicts due to poor management of the natural resources. Violent conflicts largely where local communities have been systematically excluded from decision-making processes and when the economic benefits are concentrated in the hands of a few thereby causing economic disequilibrium in the society. Misuse of the natural resources has frequently been cited as the main factor that activates, increase or support violent conflicts around the world. When the key stakeholders disagree on the management, distribution and protection of natural resources and related bionetworks. Natural resource conflicts arise when parties disagree about the management, distribution and protection of natural resources and related ecosystems. These conflicts can heighten into brutal relations and violence when the parties are incapable or reluctant to engage in a positive process of dialogue and conflict resolution. While there are many issues associated with extractive industries, the role of natural resources in triggering, escalating or sustaining violent conflict is the focus of this survey and consequently offer relevant in reducing these conflicts so that the natural resources found in Turkana County can truly be a blessing and a catalyst for poverty reduction in Turkana County. Conflict turns out to be difficult once societal mechanisms and institutions for handling and determining conflict break down, giving way to violence. Societies with weak institutions, fragile political systems and divisive social relations can be drawn into cycles of conflict and violence. Preventing this negative spiral and ensuring the peaceful resolution of disputes is a core interest of the international community. The general objective of the survey was to offer strategies in reducing conflicts associated with extractive industries. The methodology used in this survey was both qualitative and quantitative. The research design employed was descriptive survey design. The sample size was 270 heads of households and 20 stakeholders working in Turkana South and East Sub-Counties respectively. The data was collected using questionnaires and interview guides combined with observation schedules. The findings of the survey reveal that indeed extractive industries and conflicts are twins and hence there is need to address conflicts to turn natural resources into a blessing for the society.
\end{abstract}

KEY WORDS: Conflict, Extractives, Industries, Reduction, Risks, Turkana County

\section{INTRODUCTION}

In spite of oil companies claim that they are doing enough in terms of bringing development to the host communities, the host communities remain hostile and constantly at variance with the oil company. It is against such background that it becomes necessary to examine the effectiveness of the efforts of oil companies in Turkana County in answering the development needs of the host communities. Two pertinent questions in this research are: What is the community perception of the extractive industries? Will the natural resource wealth in Turkana County lead to sustainable livelihood? These are questions that require to be answered in a bid to ensure that oil discovery in Turkana County becomes a blessing and thus leading to improved standards of living among the residents of Turkana County. The presence of oil in Third World countries is a paradox. Whereas oil might be expected to spur development and eradicate poverty, the reality is countries with oil resources are the most persistent trouble spots due to poor management of the resource (Imana and Mmbali, 2016; Jill. 2006). Countries such as Nigeria have been drilling oil and instead of the oil being a blessing and boosting their economies, the local residents within the oil catchment area have become poorer thereby developing hostile attitudes to the operations of the oil companies. The ownership of land in Turkana is communal which is held in trust by the Turkana County government for the pastoralists communities although the majority of it has been allocated to oil blocks in agreements with investors (Mkutu and Wandera, 2016). 


\section{International Journal of Current Science Research and Review}

ISSN: 2581-8341

Volume 05 Issue 02 February 2022

DOI: 10.47191/ijcsrr/V5-i2-01, Impact Factor: 5.825

IJCSRR@ 2022

www.ijjcsrr.org

Behind the optimistic rhetoric of natural resources being catalysts of development, the prevailing political and security environment in Turkana County looks conspicuously similar to that which sparked insurgency in the Niger Delta: high levels of poverty, slow economic growth, poor and deprived societies, handicapped by low levels of education and health, high rates of unemployment, vulnerability to price shocks, limited economic diversification, decay in their pastoral life and agricultural sector and enclave industrialization (Yates, 2012). If left unaddressed, we could potentially see the region become a theatre for conflict associated with extractive industries. The progress and development of extraction of oil industry in Kenya is undermined by both political and economic problems which do not promote good governance and democracy (Mkutu and Lokwang, 2017)

\section{MAIN OBJECTIVE}

The general objective of this study was to find out ways of reducing conflicts associated with extractive industries in Turkana County. The study will concentrate in evaluating the perception of the local community, factors causing conflicts and lastly the effects of conflicts associated with extractives.

\section{METHODOLOGY}

The researcher used a sample size of 270 heads of households (Turkana East Sub-County: Lokori ward and Katilia ward - Total of 130 households) and Turkana South Sub-County (Lokichar ward and kalapata ward- 140 Households). An additional of 20 respondents comprising of relevant stakeholders in the area was included in the sample. They included; Leaders from the County government of Turkana, Religious leaders, NGOs and Officers working with extractive industries (see Appendix A). This was arrived at using multi stage random sampling method which requires breaking down respondents at each level until the lowest level which in this case is the village within the ward.

3.1 Sample Size: It is worth noting that it was not be possible to reach the entire population of the residents of Lokichar Basin. Therefore, a selected number of respondents were reached to obtain relevant information about the whole population and this is in line with Oso and Onen (2011). The researcher employed multi stage random sampling method to arrive at the sample size for this survey. Here the population was divided into sub-counties (Turkana East and Turkana South Sub-Counties) which were later divided into wards (In each Sub-County the researcher chose two wards) and from the wards few villages were chosen from which respondents were selected randomly for the study. The respondents were largely the people living in the current or past sites such as drilling sites or residential camps where activities of extractive industries are taking place or took place. Other respondents included stakeholders within the same vicinity who have a leadership role and thus actively involved in the affairs of the local/host community. Based on this approach, the sample size for this study was 270 heads of households (130 respondents from Turkana East Sub-County and 140 respondents from Turkana South Sub-County) and other respondents will be 20 bringing the total number of respondents to 290 - see Table 3.1 below;

Table 3.1: Sample Size

\begin{tabular}{lll}
\hline Respondents & Sample \\
\hline $\mathbf{1}$ & Household heads & 270 \\
$\mathbf{2}$ & Religious leaders & 7 \\
$\mathbf{3}$ & Oil Co. Officials & 2 \\
$\mathbf{4}$ & NGOs representatives & 3 \\
$\mathbf{5}$ & Local Chiefs & 6 \\
$\mathbf{6}$ & National and County Government Officers & 2 \\
& Total & $\mathbf{2 9 0}$ \\
\hline
\end{tabular}

The survey team was made up of four research assistants and one lead researcher bringing to a total of five people. The team worked together in each site carrying out individual interviews. The data was collected through questionnaires, informant interviews and focus group discussions. 


\section{International Journal of Current Science Research and Review}

ISSN: 2581-8341

Volume 05 Issue 02 February 2022

DOI: 10.47191/ijcsrr/V5-i2-01, Impact Factor: 5.825

IJCSRR@ 2022

www.ijjcsrr.org

4. MAIN FINDINGS

4.1 Community Perception of Extractive Industries

Table 4.1: Relationship between host communities and Extractive Industries

\begin{tabular}{lll}
\hline How do you rate your relationship with extractive industries in your area? \\
\hline & Frequency & Percent \\
Good & 52 & 21.7 \\
Very Good & 15 & 6.3 \\
Bad & 30 & 12.5 \\
Very Bad & 27 & 11.3 \\
Moderate & 116 & 48.3 \\
Total & 240 & 100.0 \\
\hline
\end{tabular}

On the question of relationship between Host community and Extractive Industries, Majority of respondents (48.3\%) describe it as being moderate, $28 \%$ of respondents consider this relationship to be generally good whereas $23.8 \%$ of the respondent's assert that the relationship between the host community and the extractive industries is bad. Moderate relationship reveals that at some stage there is conflict between the extractive industries and the host community though there are times of peaceful rapport. One of the respondents Ekeno A Aite said,

“....Ibelebelo Tullow...Akwaar na Tojoker...Moi toroner....” which translates to "...Tullow at one stage is good and at times bad..."

The host communities look at their relationship based on the benefits they receive from the extractive industries with special reference on employment (Casual labour) such that when they are employed then the extractive industries are good and once the job opportunities cease then the industries are bad since they offer no support to their livelihood. This is in line with other benefits enjoyed by the host communities as CSR from the extractive industries. The percentage of respondents who rate their relationship with extractive industries as being good are those living in Katilia Ward who have not yet experienced anything bad with Ol Suswa Co. that is yet to utilize Geothermal in their area.

\subsection{Efforts of Extractive Industries}

\section{Efforts of Extractive Industries}

$$
\square \text { Very Good Good } \square \text { Average } \square \text { Below Average }
$$

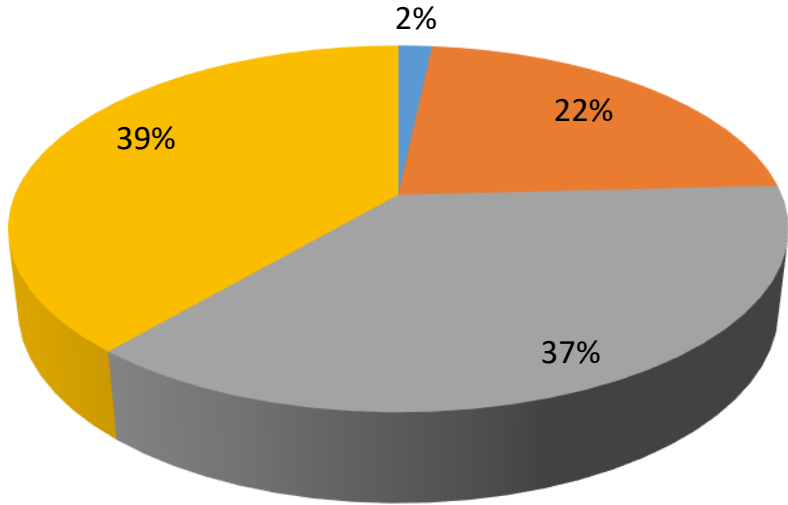

Figure 4.1: Efforts of Extractive Industries

The relationship founded on the benefits accrued is still weighed on the efforts of the extractive industries in improving living standards of the communities near their areas of operation. Figure 4.1 reveals that $39 \%$ of the respondents view the efforts of the 


\section{International Journal of Current Science Research and Review}

ISSN: 2581-8341

Volume 05 Issue 02 February 2022

DOI: 10.47191/ijcsrr/V5-i2-01, Impact Factor: 5.825

IJCSRR@ 2022

www.ijjcsrr.org

extractive industries being below average, $37 \%$ rate these efforts as average, $22 \%$ of the respondents acknowledge efforts of the extractive industries as being good and $2 \%$ view them as being very good. This is a reflection of a community that is not yet satisfied with the interventions of the extractive industries and hence their relationship cannot be well founded. Consequently, this dissatisfaction becomes a ground of misunderstanding and hence catalyzes conflicts.

Table 4.2: CSR Efforts of Extractive Industries

\begin{tabular}{clcl}
\hline \multicolumn{3}{c}{ Are you satisfied with the CSR activities of the Oil Co.? } \\
\hline & & Frequency & Percent \\
Yes & 3 & 20.0 \\
No & 12 & 80.0 \\
Total & 15 & 100.0 \\
\hline
\end{tabular}

Majority of the leaders are not satisfied with the efforts of the extractive industries. This is an echo of the local community concerns and thus creating an atmosphere of animosity against the extractive industries. The rating of these CSR efforts is seen in the infrastructural development within the region. The respondents expressed that they cannot be able to proudly say that they have seen major infrastructural development in their region since the advent of extractive industries. $37.5 \%$ of the respondents stated that extractive industries have contributed to infrastructural development at a low extent, $30.8 \%$ of the respondents consider it to have contributed moderately, $18.8 \%$ have not seen any effect on infrastructural development, $7.5 \%$ have no idea of any development contributed by the presence of extractive industries whereas $5.4 \%$ of the respondents rate infrastructural development highly.

Table 4.3: Contribution of Extractive industries to infrastructural development

\begin{tabular}{lll}
\hline Improved infrastructure & & \\
\hline & Frequency & Percent \\
Highly & 13 & 5.4 \\
Moderately & 74 & 30.8 \\
Low & 90 & 37.5 \\
Not affected & 45 & 18.8 \\
I dont Know & 18 & 7.5 \\
Total & 240 & 100.0 \\
\hline
\end{tabular}

Water a basic need is still a problem in the areas where activities of extractive industries are taking place. The local residents in Lokicheda near Ngamia 1 (see Photo 4.1), which is the first oil well do not have a reliable water source and to date rely on water tankering by Tullow Oil. Therefore, the situation of water inadequacy still remains. Here below is a water tank that water is put for consumption by the local community. This would have been better if there was a borehole for the local community rather than waiting for weekly supply of water by the tankers.

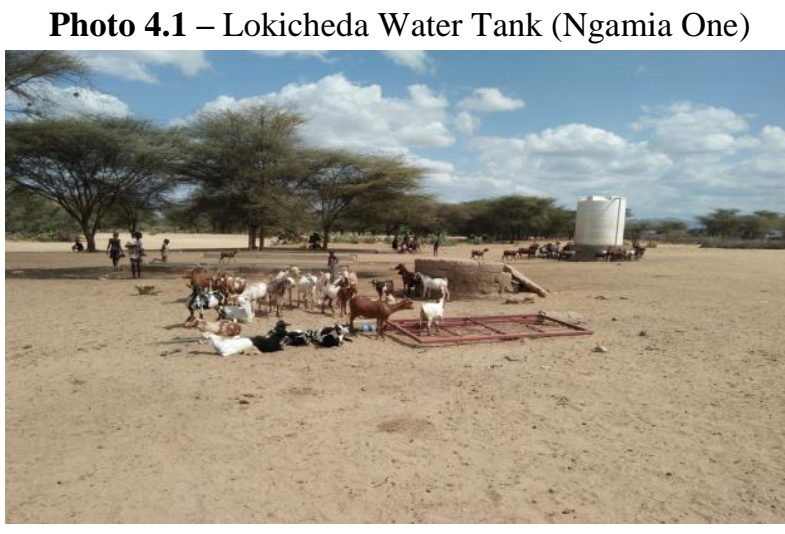

Photo 4.2 - Classrooms Block (Ngamia One)

Source: Author

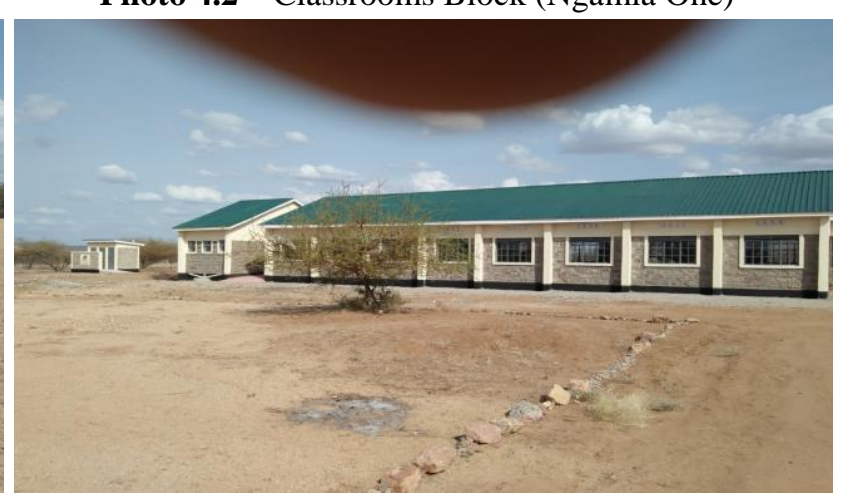




\section{International Journal of Current Science Research and Review}

ISSN: 2581-8341

Volume 05 Issue 02 February 2022

DOI: 10.47191/ijcsrr/V5-i2-01, Impact Factor: 5.825

IJCSRR@ 2022

www.ijcsrr.org

Ngamia One High School has only benefitted with one Classroom block from Tullow Oil Co (see Photo 4.2), yet this school would be expected to be a great beneficiary by virtue of being the only secondary school near the 'mother' of all oil wells in Turkana County.

\subsection{Conflict Analysis}

\subsubsection{Existence of Conflicts}

Looking at the kind of relationship between the host community and the extractive industries as a result of dissatisfaction from the local community, majority of respondents confirmed that indeed they have witnessed on several occasions conflicts between the host community and the extractive industries. The few respondents who said no to the prevalence of conflicts are those from Katilia ward who so far have not experienced any conflicts given that Ol Suswa Co. that is concerned with Geothermal has not actually gone into major operations in the area. The residents are yet to see if there will be any conflict arising from exploitation of Geothermal.

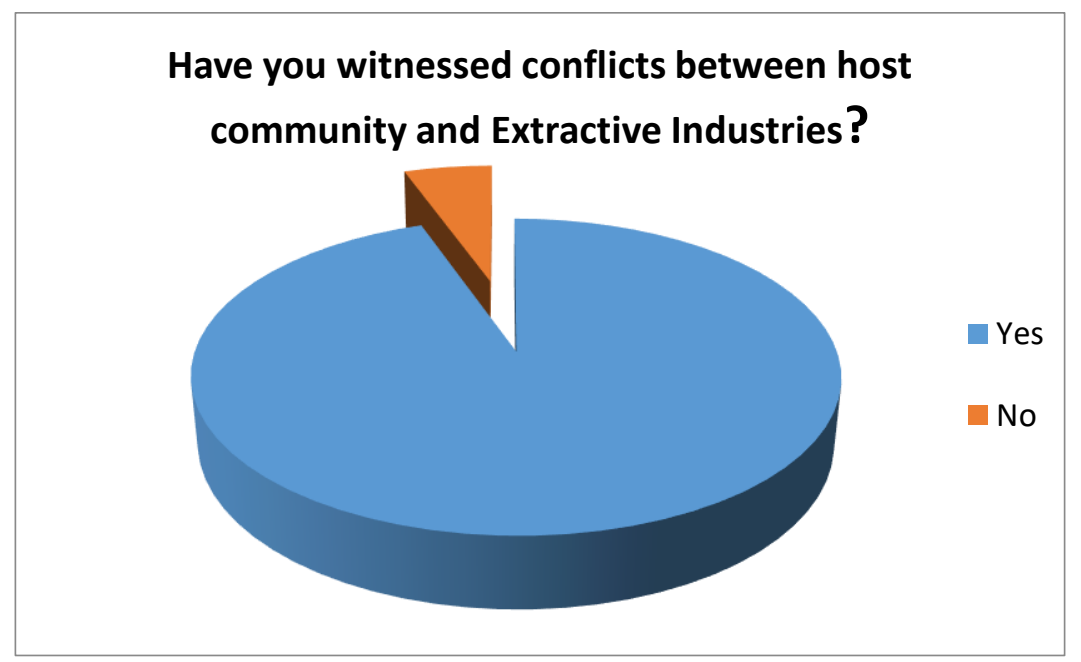

Figure 4.2: Conflicts between host community and extractive industries

At the time of the survey, the residential camps of Tullow Oil Co. were closed due to the tension in the area following demonstrations of a dissatisfied community.

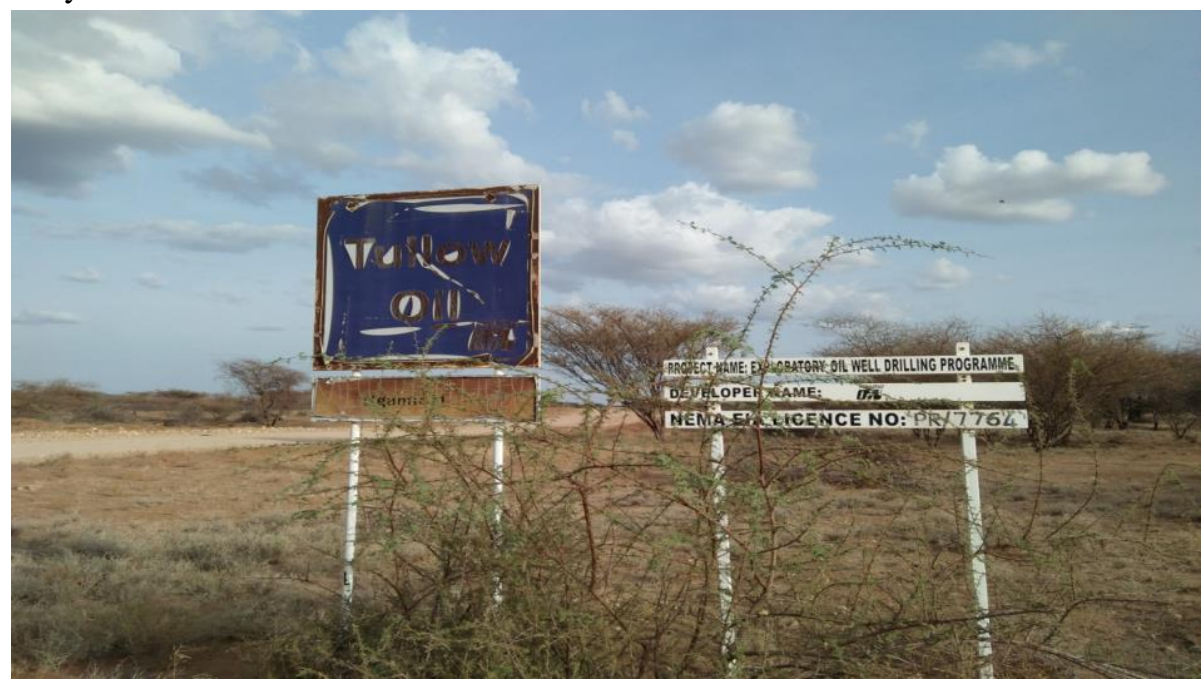

Source: Authors 


\section{International Journal of Current Science Research and Review}

ISSN: 2581-8341

Volume 05 Issue 02 February 2022

DOI: 10.47191/ijcsrr/V5-i2-01, Impact Factor: 5.825

The local communities where Oil exploration activities have been done have on many occasions demonstrated against extractive industries. Upon looking at the conflict parties, majority of the respondents assert that the parties in these conflicts are mainly Tullow Oil Co. and the local residents living near the oil sites of course in collaboration with the residents of the larger Turkana County.

\subsection{2: Parties in Conflicts associated with Extractive Industries}

Table 4.4: Parties to conflicts associated with extractive industries

\begin{tabular}{lll}
\hline \multicolumn{2}{l}{ Parties to conflicts associated with extractive industries } & \\
\hline & Frequency & Percent \\
Tullow Oil and host community & 185 & 77.1 \\
Host Community and GOK & 41 & 17.1 \\
Host Community members & 14 & 5.8 \\
Total & $\mathbf{2 4 0}$ & $\mathbf{1 0 0 . 0}$ \\
\hline
\end{tabular}

$77.1 \%$ respondents assert that the major parties in these conflicts are Tullow Oil Co. and the host communities, $17.1 \%$ see the parties to the conflicts being the host community and the Government of Kenya and this especially when the local community feels not protected and supported by the government when they feel shortchanged by Tullow Oil Co. On the other hand 5.8\% of the respondents agree that at times there is conflict between themselves in the case where for example one community member loses a job and replaced by another which brings a feeling of mistrust between community members. One respondent had this to say in regard to intra-community conflict

“....Kiteremok kolong sua Tullow kotere na ipusia ipei etic sodi kigir nabo nice...Atamasi robo..ekwa ca been ati kisipusi ayong emoit.." (...When a member of a community loses his/her job the feeling is that the one who has taken their place is the cause and in this case the replacement of a fellow community member...)

A close look at the major parties to the conflict brings Tullow at the centre and the local community hence the assertion of the majority of the respondents holds water. Looking at the nature of this conflict, the respondents are worried that extractive industries in their area will leave one legacy...Death is the only legacy that extractive industries will leave in Turkana County as asserted by one elder :

“.....Ebunit akmiet na ka Tullow keng amunyar Ngiturkana...Akitu bon kidarit...( Conflicts associated with Extractive industries will finish us...we are only waiting for death as a result of the presence of extractive industries in this region..."

This assertion goes in line with the words of Amstel Monday Gbarakpor who had this to say on exploration of oil in Nigeria "......The only legacy that oil has brought to Niger Delta is death..."

\subsubsection{Factors Contributing to conflicts Associated with Extractive Industries Poor Community engagement}

Table 7: Poor Community engagement

\begin{tabular}{lll}
\hline \multicolumn{2}{l}{ Views of local community are not taken into consideration } \\
\hline & Frequency & Percent \\
True & 199 & 82.9 \\
Not True & 29 & 12.1 \\
I dont Know & 12 & 5.0 \\
Total & 240 & 100.0 \\
\hline
\end{tabular}

One factor that causes conflicts between the host community and the extractive industries is poor community engagement. $82.9 \%$ of the respondents agree to the fact that not taking into consideration the views of the local community has been a cause of conflict between the host community and the extractive industries. On the other hand $12.1 \%$ of the respondents consider this factor as not being true whereas $5 \%$ do not know whether not considering their views can lead to conflicts with the extractive industries. The 


\section{International Journal of Current Science Research and Review}

ISSN: 2581-8341

Volume 05 Issue 02 February 2022

DOI: 10.47191/ijcsrr/V5-i2-01, Impact Factor: 5.825

local community feels disrespected when their views are not considered. Such was the case with the latest demonstrations after the launch of the EOPS.

When the local residents are poorly engaged, marginalised or excluded from the dialogue in the development process, they are almost certain to begin to oppose the development. This is particularly the case where they have not been consulted on whether the development should proceed at all, especially if there is the risk that they will bear the impacts and fail to benefit. As the conflict escalates, the use of strategies of violence as a coercive measure against the company and a means for addressing old grievances and mounting opposition against the government are likely to occur

Young unemployed population is prone and volatile to conflicts

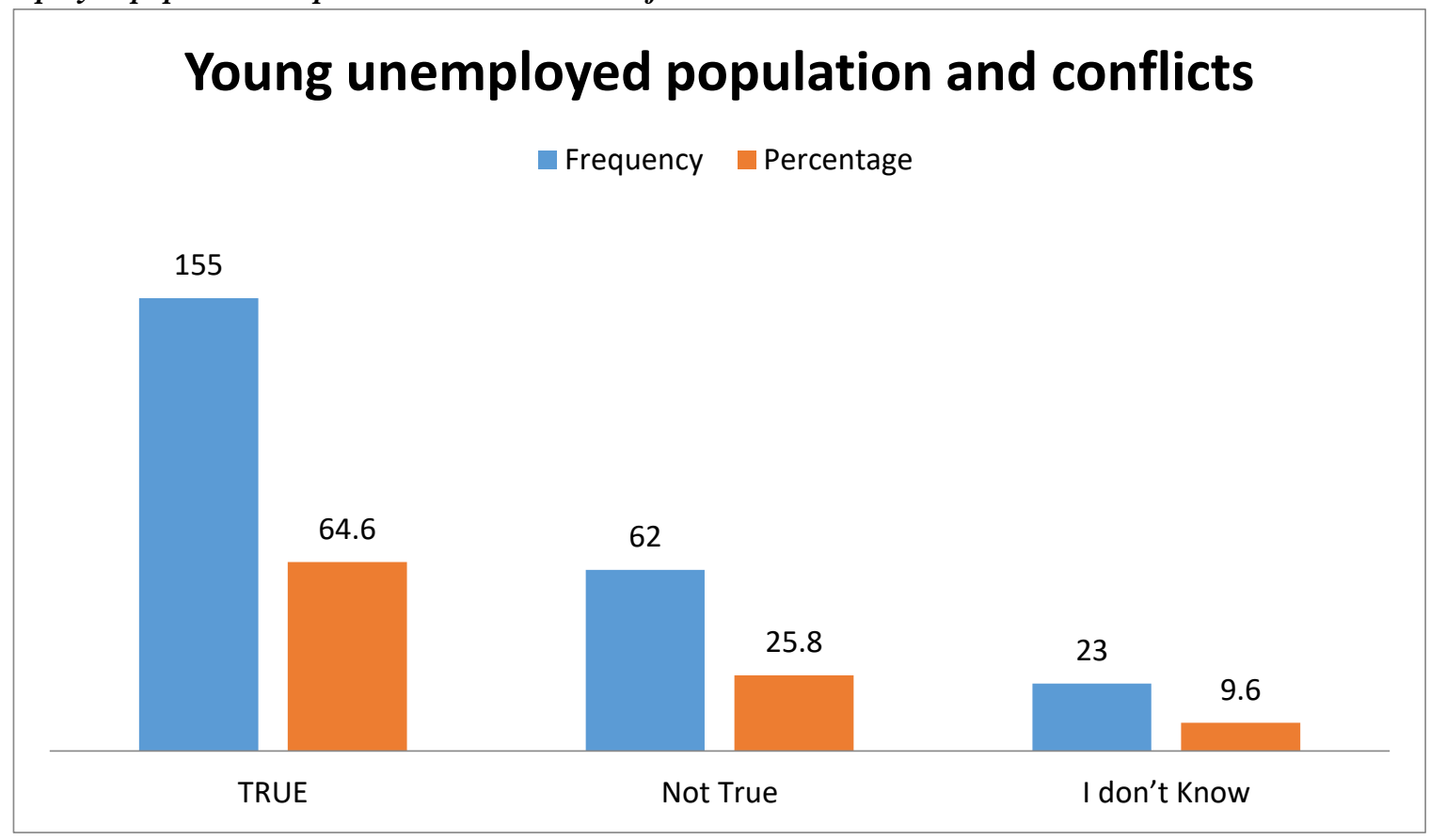

Figure 1: Young unemployed population and Conflicts

Young people who are unemployed are at the risk of being used to cause conflicts and given their situation they go into it since they consider themselves as having nothing to lose after all. $64.6 \%$ of respondents are affirmative on the role played by young unemployed population in conflicts as active agents, $25.8 \%$ consider this assertion as being not true whereas $9.6 \%$ do not know whether young people can be agents of conflicts given their vulnerable situation of unemployment. Extractive industries have scored low in creation of employment and thus young people who are looking for employment shift their energy and time to demonstrate against extractive industries.

\section{Benefit sharing and Conflicts}

The most recent cause of conflicts between the local community and the extractive industries is unclear benefit sharing. Majority of the respondents $(98.8 \%$ ) allude to the verocity of associating natural resource-related conflicts to the unclear benefit sharing, $0.8 \%$ of the respondents deny this fact whereas $0.4 \%$ are not aware of the fact that unclear benefit sharing has contributed to the tension between the local community and the extractive industries. The local residents claim that at the launch of the EOPS in Ngamia 1, the agreement was that they (local community) would be given their 5\% share in form cash transfer but to their surprise things changed as soon as the first truck carrying oil to the refinery were released. On realizing this was mischief, the local community then resorted to block further transportation of crude Oil from Turkana County. 
ISSN: 2581-8341

Volume 05 Issue 02 February 2022

DOI: 10.47191/ijcsrr/V5-i2-01, Impact Factor: 5.825

IJCSRR@ 2022

www.ijcsrr.org

\title{
Unclear benefit sharing scheme has led to conflicts with extractive indsutries
}

\author{
Frequency Percentage
}

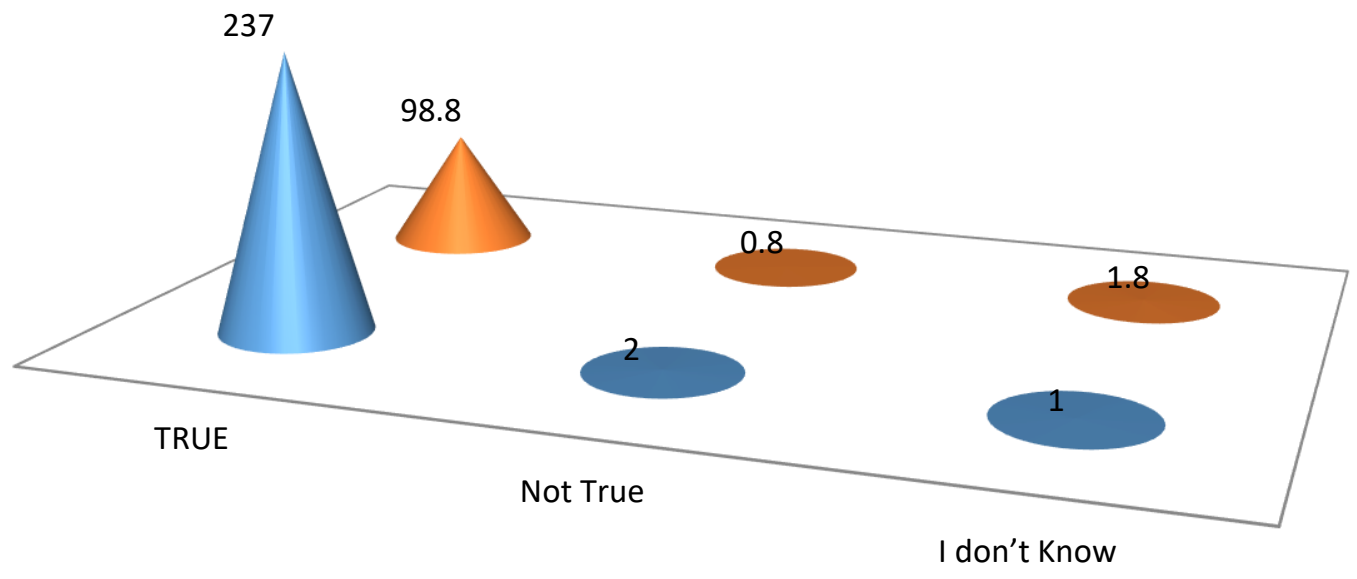

Figure 2: Unclear benefit sharing has led to conflicts with extractive industries

One respondent had this to say “....Kipiak nakad...We need to be given our share in form of cash transfer to our personal accounts without which we cannot let oil be transported outside Turkana..." The local residents argue that the only way they can directly reap the benefits of the natural resources on their region is through getting cash transferred to their accounts just like the famous "lopetun" in the County.

If benefits are distributed in a manner that appears unfair as compared to the distribution of the costs, risks and responsibilities, then those who are disenfranchised or bearing risks and responsibilities without fair compensation will rebel. It is this then that explains why the Turkana people are not happy with the percentage given to them and even worse that they cannot get the revenue in form of cash.

\section{Land and Conflicts}

Table 8: Land and Conflicts

\begin{tabular}{lll}
\hline \multicolumn{2}{c}{ There have been more land conflicts since exploration of Oil in the area } \\
\hline & Frequency & Percent \\
True & 185 & 77.1 \\
Not True & 41 & 17.1 \\
I dont Know & 14 & 5.8 \\
Total & 240 & 100.0 \\
\hline
\end{tabular}

$77.1 \%$ of the respondents assert that it is true that land conflicts have gone to the rise since the coming of the extractive industries, $17.1 \%$ of the respondents consider this statement not being true while $5.8 \%$ of the respondents do not know the magnitude of land conflicts. Land in Turkana community is communally owned from time immemorial but the presence of extractive industries has led to private ownership of land, a shift that has led to people fighting over access and control of land (See Appendix C). On realizing that land can be exchanged for monetary gain, the local residents have organized themselves in groups to own land which they will later on lease to the extractive industries for monetary gain. These local land groups have led to clashes among community members. 


\section{International Journal of Current Science Research and Review}

ISSN: 2581-8341

Volume 05 Issue 02 February 2022

DOI: 10.47191/ijcsrr/V5-i2-01, Impact Factor: 5.825

Land tenure contributes to conflict when land ownership, management and access are deemed to be unjust or unequal, or when customary practices conflict with formal laws. Pastoralists have lost their grazing land to the extractive industries and so they can in no way bring their animals to graze anywhere near the residential camps or working sites of the extractive industries. Any attempt to access grazing land near the established camps of extractive industries has been futile and thus a cause of dissatisfaction from the side of the local community.

\section{Lack of Compensation}

The local community have had issues with the extractive industries especially Tullow Oil Co. on grounds that they have not been compensated yet they bear the consequences of their activities and above all especially because they gave land to the extractive industries for their residential camps and other activities.

Among the consequences for which the local community requires compensation include: Degradation of the local environment, loss of land and displacement which have direct impacts on human health and the productivity of agriculture and other forms of traditional economic activity.

\section{Have you been compensated}

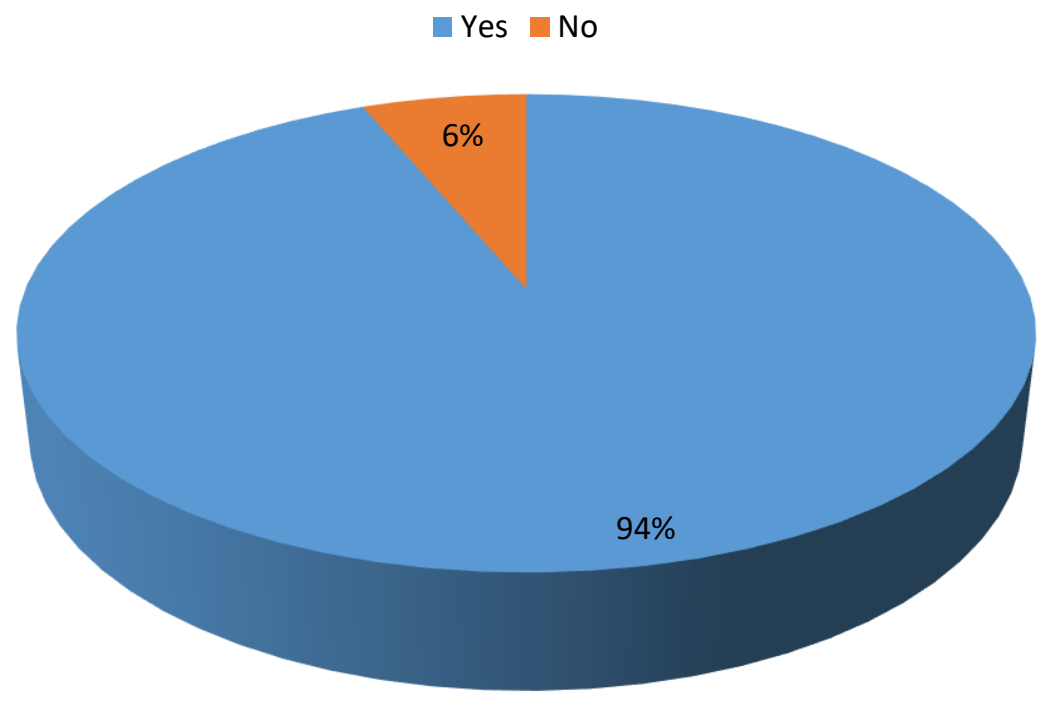

Figure 5: Have you been compensated?

Majority of the respondents revealed that the extractive industries have not compensated the local community for the land taken for residential camps and other activities while a minority acknowledged having been received compensation for the loss of land. So far only a few wells (Amosing 6, Amosing 7, Ngamia 9 Ngamia 10) have been compensated each Ksh $7 \mathrm{~m}$ while the compensation expected for all the other oil wells has not been given. The fact that the land taken by the extractive industries has not been compensated to date yet this was the initial agreement at the time of lease of land contributes to the conflicts between the local community and the extractive industries. This forms part of the unfulfilled promises. One respondent had this to say

".....Tullow Oil Co. have cheated us for long... When they asked for the land they told us that we lease the land to them after which they will compensate us for the loss of land... To date... we have not been compensated"

The local community blames Tullow over unfulfilled promises and this fuels the conflict between the local community and the extractive industries. Among the unfulfilled promises that would form part of compensation apart from money includes:

- Creation of employment

- Award of tenders

- Provision of relevant and necessary community needs such as water, health facilities and support for education 


\section{International Journal of Current Science Research and Review}

ISSN: 2581-8341

Volume 05 Issue 02 February 2022

DOI: 10.47191/ijcsrr/V5-i2-01, Impact Factor: 5.825

IJCSRR@ 2022

www.ijjcsrr.org

- Infrastructural development

According to majority of the respondents, extractive industries have scored below average in the fulfillment of their promise s and hence opening a window of conflict.

\section{Inadequate institutional and legal framework}

The mismanagement of funds is symptomatic of the broader institutional and legal capacities to manage the development of EI for the benefit of the country as a whole. Majority of respondents confirm that there is inadequate institutional and legal framework in the management of natural resource find in Turkana County. On the other hand, a minority of the respondents acknowledge that the absence of legal and institutional framework cannot be attributed to the rampant conflicts between the local community and the extractive industries.

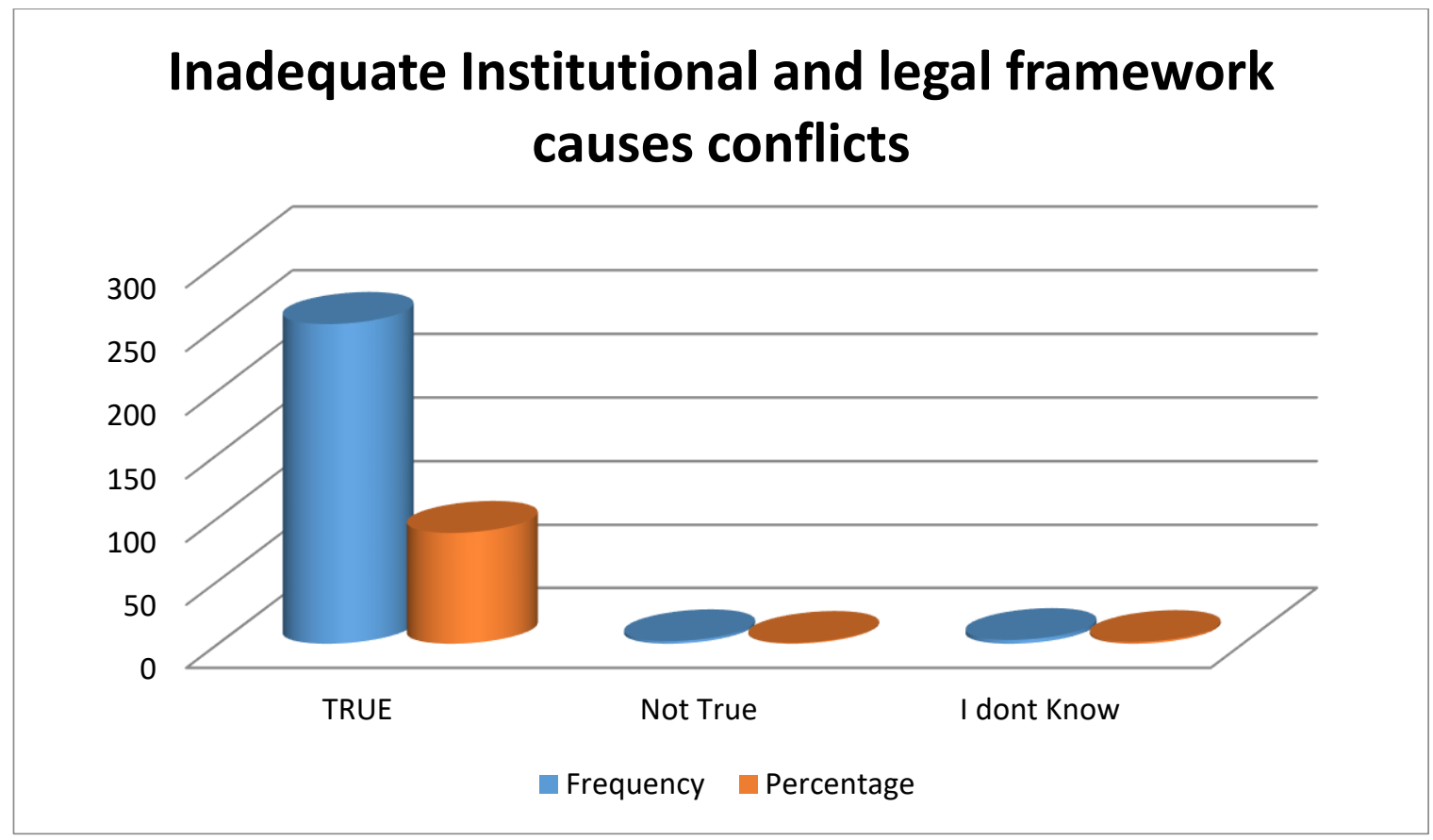

Figure 6: Inadequate institutional and legal framework causes conflicts

Due to the gap in the rule of law, revenues from EIs often concentrate wealth and power in the hands of the few, thereby exacerbating inequality, poverty and levels of corruption. This legal gap opens ground for the mismanagement of resource benefits thus leading to dissatisfaction which consequently leads to conflicts.

\subsubsection{Mediator between Local Community and Extractive Industries}

Conflict resolution requires that there be a mediator between the conflict parties. With regard to the conflict between the local community and the extractive industries, $58.3 \%$ of the respondents trust the Church as a mediator arguing that the Church has men and women of faith who are selfless and put the interest of the vulnerable people as a priority. However the respondents pointed out the long silence of the Church especially the CJPC in their conflict with extractive industries. One respondent said:

“...Nyikinyami ituan e kanisa aramu kotere anupit Akuj...Nyai ni Kolong ipotu eesi tongopiasi kimiekis sua ka emoit kijii akoyen..( Church people are not corrupt and so can be good mediators.. We have waited for you for long to help us in resolving these conflicts yet for long you were nowhere and left us to fight with the extractive industries Co..." 


\section{International Journal of Current Science Research and Review}

ISSN: 2581-8341

Volume 05 Issue 02 February 2022

DOI: 10.47191/ijcsrr/V5-i2-01, Impact Factor: 5.825

IJCSRR@ 2022

www.ijcsrr.org

Table 9: Who do you as a community trust as a mediator for your benefit?

\begin{tabular}{lll}
\hline Who can you as a community trust as a mediator to advocate for your benefit? \\
\hline & Frequency & Percent \\
Church & 140 & 58.3 \\
Government Leaders & 36 & 15.0 \\
NGOs & 35 & 14.6 \\
Politicians & 29 & 12.1 \\
Total & 240 & 100.0 \\
\hline
\end{tabular}

Therefore the role of the Church as affirmed a majority of respondents in mediation is so great and cannot be underestimated. This is a role that for some time was missing in the affairs of the extractive industries in Turkana County. The Church (CJPC) enjoys much trust from the local community.

$15 \%$ of the respondents trust government leaders especially the Chiefs and elders in mediating in their conflicts, whereas $14.6 \%$ trust NGOs and $12.1 \%$ trust politicians as mediators. Respondents argued that their little trust in the three groups is based on the fact that these leaders are always manipulated by the extractive industries investors. Government leaders, NGOs and politicians have been painted as being easily bribed by the extractive industries and hence do little if not none to help them get their grievances properly addressed. One respondent said “.... Whenever we have conflicts with extractive industries...our leaders go into a closed door meeting with Tullow Co. officers...they come out of the meeting without any substantive resolution.... we do not know what they are given inside those rooms...". This raises concern over leaders being bribed not to really seek the best for the conflict parties.

\subsubsection{Effects of conflicts Associated with Extractive Industries}

Conflicts associated with extractive industries have a double-fold effect such that they affect both the local community and the extractive industries.

\section{Effects of Conflicts}

\section{Insecurity $\square$ Loss of Jobs Withdrawal of services}

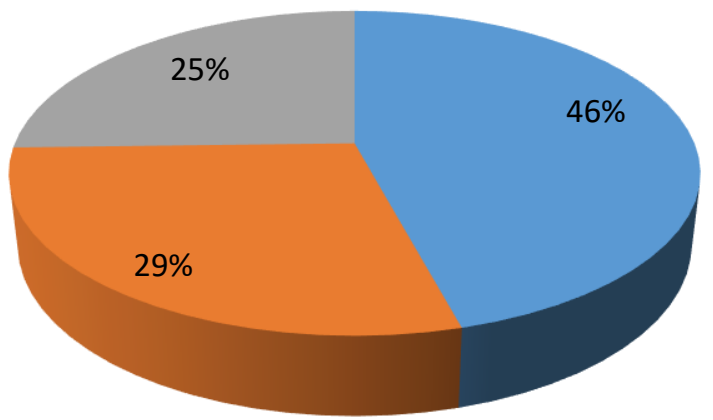

Figure 7: Effects of Conflicts

$46 \%$ of the respondents see insecurity being in the rise a as result of conflicts associated with extractive industries. When the activities of the extractive industries are on, usually there are patrols on the road and hence people move freely from one point to another. Some of the places taken by extractive industries as residential camps are insecure and so the daily patrols by the vehicles of the extractive industries boost security of these routes. At the same time, employees of the extractive industries are also insecure and thus sent away from the residential camps when there is a conflict in the fear of the residential camp being raided by the locals. 


\section{International Journal of Current Science Research and Review}

ISSN: 2581-8341

Volume 05 Issue 02 February 2022

DOI: 10.47191/ijcsrr/V5-i2-01, Impact Factor: 5.825

$29 \%$ of the respondents point out loss of jobs as an adverse effect of the conflicts. Those employed by the extractive industries lose their jobs since no activity goes on at the time of conflict. This also affects the extractive industries since their work comes to a standstill and thus costing them. This will eventually lead to slow recovery of cost of production and thus no maximization of profit on the part of the extractive industries.

$25 \%$ of the respondents argue that when there is conflict between the local community and the extractive industries, the services given to the community are withdrawn. One respondent said "...When we are in conflict with extractive industries...water supply with the tankers is stopped and so we do not get water as usual..." Another effect of these conflicts is a drop in business gain since no cash flow from both sides.

\section{RECOMMENDATIONS}

\subsection{Effective engagement of local communities}

There is need for meaningful engagement of local communities in the activities of the extractive industries. Constant engagement enhances the relationship between the local community and the extractive industries. While the underlying conflicts between development objectives and community values may generate real tensions, those tensions are far less likely to escalate into violent conflict if those affected can play a decisive role in the decision-making processes. Engagement of local community leads to them owning the natural resource in their region and a sense of being valued. This can be promoted through consultation and enabling the local community to be active participants in the management of the natural resources found in their area.

\subsection{Clear and Equitable benefit-sharing Scheme}

Local community ought to be made aware of their share of the benefits and the benefit sharing need to be equitable. Benefits to communities and regions need to be in the form of barter contracts and direct cash transfer. Barter contracts can take the form of infrastructure, employment, contracting opportunities, and general economic development. These benefits can be provided to communities and regions as a whole as well as to specific communities living near the drilling sites and residential camps of the extractive industries. If these benefits are consistent with community interests, and are perceived to be delivered fairly, they can help prevent conflict. The local community can also be given direct cash transfer and this has been voiced by the local residents in various fora.

\subsection{Employment Creation}

Extractive industries need to create employment for the local community within the companies that service them. Employment be clear on the allocation of positions within the companies and possibly take affirmative action in ensuring that employment is well spread.

\subsection{Transparency}

It is important to make public information because this reduces suspicion and enhances trust between the parties involved. The local community ought to be aware of activities of extractive industries which they seem to be vaguely known and hence breeding suspicion. A vigorous and diverse mass media is an essential cornerstone of a free and open society, and helps to establish and maintain transparency. Strengthening their capacity and independence thus becomes a critical component of efforts aimed at ensuring that revenues are invested in the public interest.

\subsection{Rule of Law}

A profound institutional and legal framework is necessary to guide the relationship between the local community and the extractive industries. With an established legal framework pertinent issues of revenue sharing can be well stipulated and implemented. Legal framework will stipulate the rights and obligations of both the local community and the extractive industries and will form the basis of rights-based approach in the exploration of natural resources in Turkana County.

\subsection{Establishment of grievance Management Committee}

There is need to establish mechanisms of addressing grievances of the local community. This requires establishment of structures and more important is having office in place that will be able to mediate between the local community and the extractive industries. 


\section{International Journal of Current Science Research and Review}

ISSN: 2581-8341

Volume 05 Issue 02 February 2022

DOI: 10.47191/ijcsrr/V5-i2-01, Impact Factor: 5.825

\subsection{Sensitization of the local community}

The local residents need to be fully aware of all that pertains to exploration of natural resources so that every decision they take is an informed decision. Apparently the local residents are misinformed about certain issues especially on the implications of exploration of natural resources and it is this misinformation that occasionally leads to conflicts.

\section{REFERENCES}

1. Imana, D. K., \& Mmbali, O. S. (2016). Envisioning incentives for inclusivity in natural resource management: A case study of oil extraction in Northwest Kenya. Open Science Publishers, 1(2), 15.

2. Obiri, J. (2016): Conflicts arising from Oil and Gas Extraction in Turkana County, Kenya. The $2^{\text {nd }}$ Oil and Gas

3. Conference in Turkana County, Kenya at Cradle Hotel, Lodwar Kenya. Retrieved on 12.01.2022 from https://www.researchgate.net/publication/304830866_Conflicts_arising_from_Oil_and_Gas_Extraction_in_Turkana_Co unty Kenya

4. Oso, Y. W., \& Onen, D. (2011). A General Guide to Writing Research Proposal and Report (Revised ed.).

5. Ross, M. L. (2012). The Oil Curse: How Petroleum wealth shapes the development of nations. New Jersey: Princeton University Press.

6. Schillings, J., Akuno, M., Scheffran,J., \&Weinzierl,I. (2012). On raids and relations: Climate Change, Pastoral Conflict and Adaptation in NorthWestern Kenya. In S. Bronkhosrt, \&U.

7. Shankleman, J. (2006). Oil Profits and Peace: Does Business have a role in peace-making? Washington: United States Institute of Peace Press.

8. Yates, D. A. (2012). Scramble for African Oil: Oppression, Corruption and War for Control of Africa's Natural Resources. London: Pluto Press.

9. Mkutu, K., \& Lokwang, A. E. (2017). New challenges for African potentials in mediating conflicts: The case of Turkana, Northwestern Kenya. African virtues in the pursuit of conviviality: Exploring local solutions in light of global prescriptions, 73.

10. Mkutu, K., \& Wandera, G. (2016). Conflict, Security and the Extractive Industries in Turkana, Kenya: Emerging Issues 2012-2015. Kenya School of Government.

\section{APPENDICES}

Appendix A: Distribution of survey sites

\begin{tabular}{|c|c|c|}
\hline SUB-COUNTY & WARD & VILLAGES \\
\hline \multirow[t]{2}{*}{ Turkana East } & Lokori/ Kochodin & $\begin{array}{ll}\text { - } & \text { Lokori } \\
\text { - } & \text { Lopii } \\
\text { - } & \text { Nakukulas } \\
\text { - } & \text { Lokicheda }\end{array}$ \\
\hline & Katilia & - $\quad$ Elelea \\
\hline \multirow[t]{2}{*}{ Turkana South } & Lokichar & $\begin{array}{ll}\text { - } & \text { Lokichar } \\
\text { - } & \text { Kasuroi } \\
\text { - } & \text { Kapese } \\
\text { - } & \text { Lomokomar } \\
\text { - } & \text { Karoge } \\
\text { - } & \text { Lochwangikamatak }\end{array}$ \\
\hline & Kalapata & $\begin{array}{ll}\text { - } & \text { Loperot } \\
\text { - } & \text { Kaimegur }\end{array}$ \\
\hline
\end{tabular}




\section{International Journal of Current Science Research and Review}

ISSN: 2581-8341

Volume 05 Issue 02 February 2022

DOI: 10.47191/ijesrr/V5-i2-01, Impact Factor: 5.825

IJCSRR@ 2022

www.ijcsrr.org

Appendix B: Researchers Field Photos

(a)Research Assistant, Mr. Tonny Adome with a herdsman - respondent

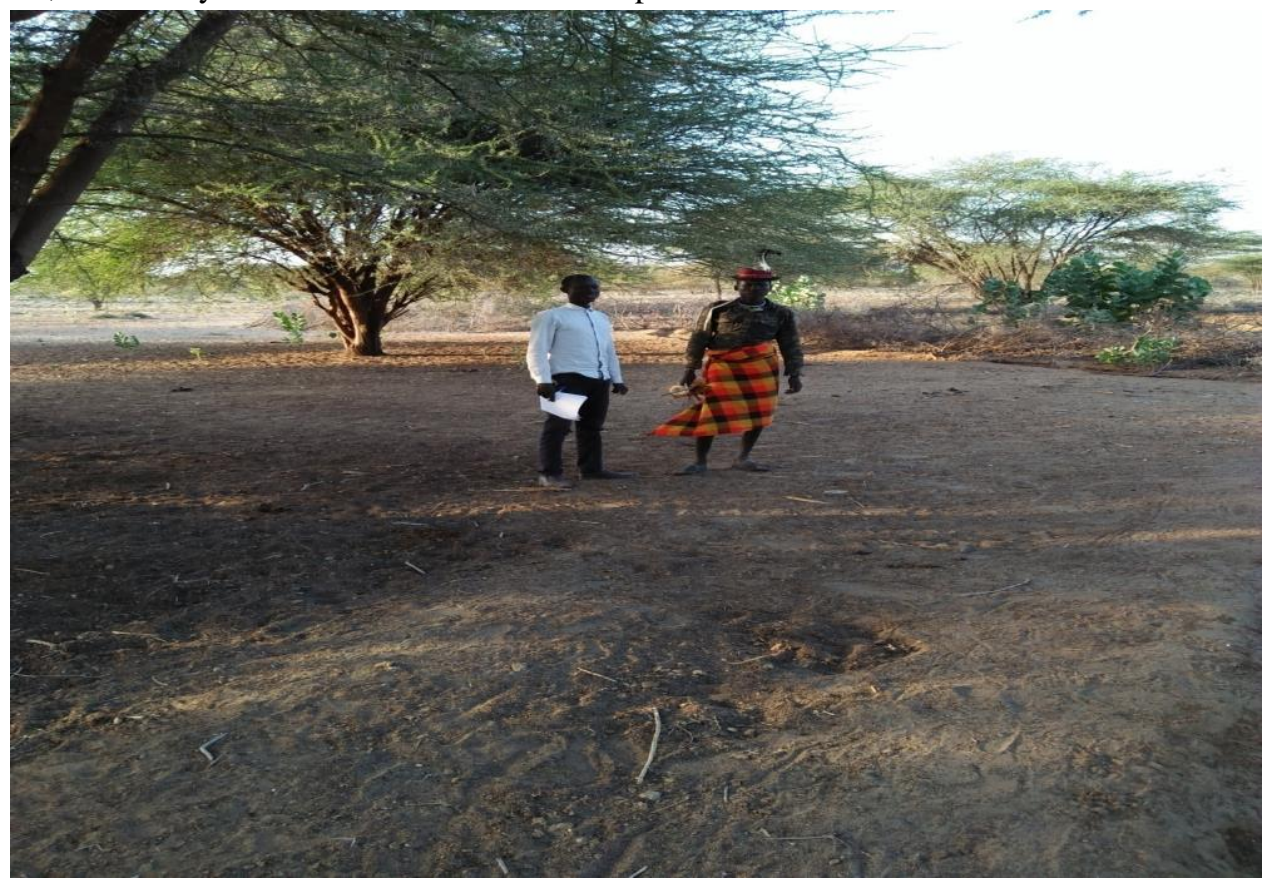

Source: Owner

(b) Lead Researcher, Rev. Fr. Paul Areman at Lokicheda primary school in Lokicheda Village

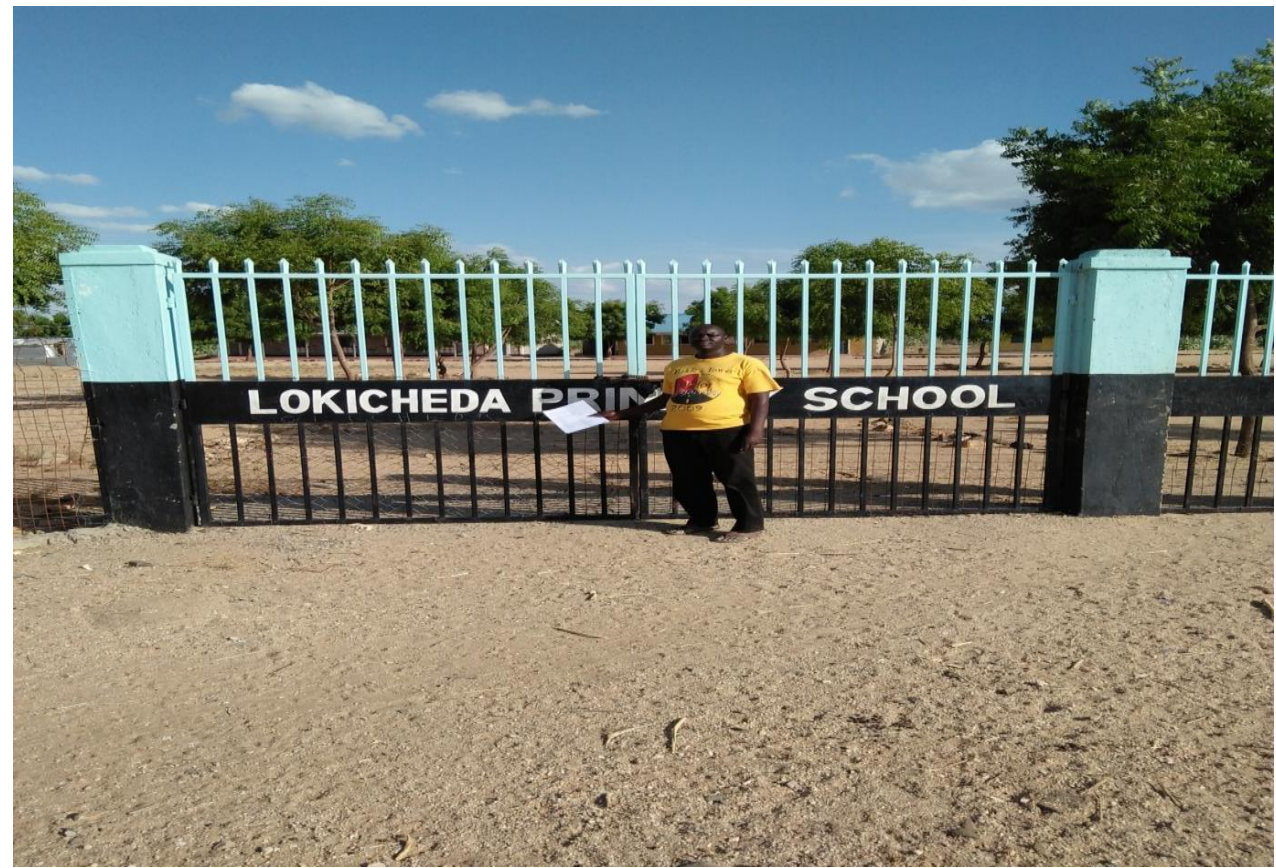

Source: Owner 


\section{International Journal of Current Science Research and Review}

ISSN: 2581-8341

Volume 05 Issue 02 February 2022

DOI: 10.47191/ijcsrr/V5-i2-01, Impact Factor: 5.825

IJCSRR @ 2022

Appendix C: Map of Turkana County with Oil Sites Marked Red

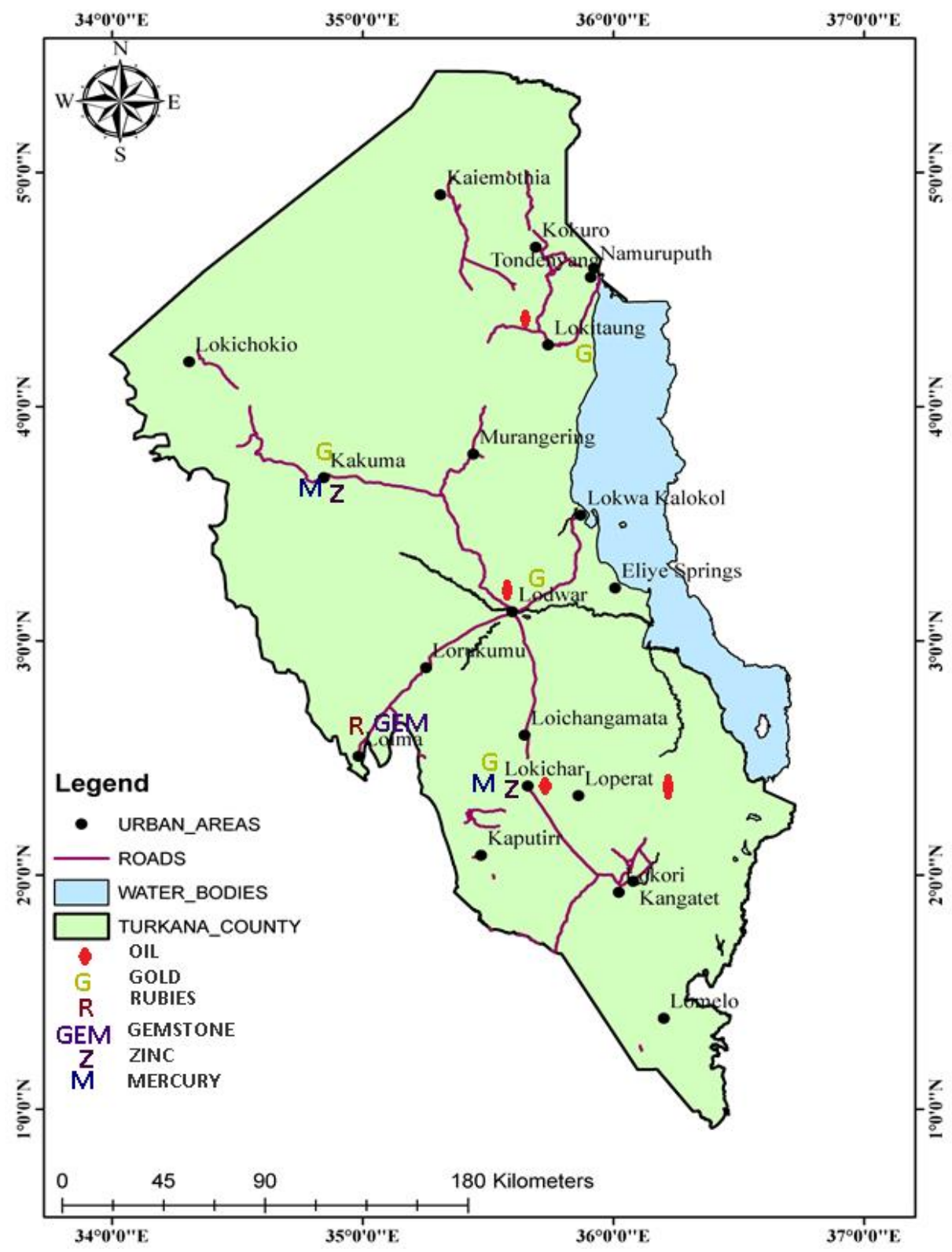

Source: Obiri (2016)

Cite this Article: Fr. Areman L. Paul, Prof. Joshua Kwonyike, Prof. Leonard S. Mulongo, Dr. David Kamar Imana (2022). Extractives Industries and Conflict: Reduction of Risks Associated with Extractive Industries in Turkana County, Kenya. International Journal of Current Science Research and Review, 5(2), 291-305 